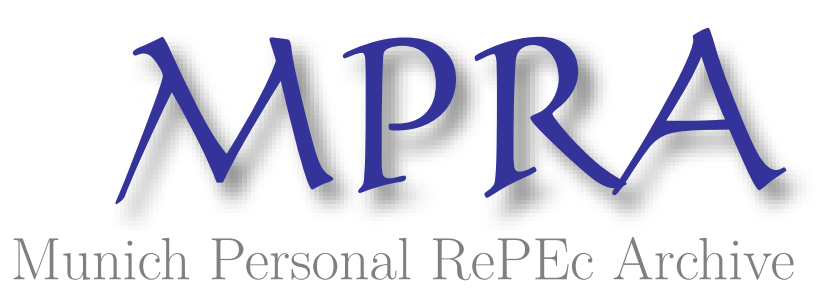

\title{
Analyzing Challenges Opportunities of Ethiopian SMEs: Micro Macro Economic Drivers
}

Sapovadia, Vrajlal

American University of Nigeria

2015

Online at https://mpra.ub.uni-muenchen.de/68778/

MPRA Paper No. 68778, posted 13 Jan 2016 07:26 UTC 


\section{Analyzing Challenges \& Opportunities of Ethiopian SMEs: Micro \& Macro Economic Drivers}

Dr. Vrajlal Sapovadia. Professor \& Associate Dean, School of Business \& Entrepreneurship, American University of Nigeria Yola, Nigeria

\section{Prologue:}

The Ethiopian economy is dominated by the agriculture and services sectors, with each accounting for about 43-44 percent of gross domestic product (GDP), leaving only about 13 percent for industry of which manufacturing accounts for about 6-7 percent ${ }^{1}$. The low industrial contribution is attributed to lower participation of private enterprises; thanks to lack of encouraging policy \& conducive environment for entrepreneurs. This research proposal aims at investigating inhibiting factors of growth at micro, macro \& meta level. Industrial development and entrepreneurship are two side of a coin. Entrepreneurship encompasses the promoters, government and financial institutes. Entrepreneurship development is essential to solve the problem of economic development through creating local employment, balanced area development, decentralization of economic power and diversion of profits from rich to middle class \& poor. Many local innovations go unnoticed because of innovator's limitations in commercialize the product. An apex institute may be set up to help and promote commercialization of low cost local innovations. If stakeholders of entrepreneurship work in tandem, SMEs can grow fast.

As per 'Doing Business Report 2015'2 published by the World Bank Group'; Ethiopia is ranked $132^{\text {nd }}$ with distance to frontier (DTF) scores of 56.31. The internal factors to arrive on aforementioned rank \& score reveal that Ethiopia poorly performed on starting business, trading across boarder, access to credit, protection of minority investors, paying taxes and registering property. The following table depicts the score and ranks.

\begin{tabular}{|l|l|l|l|}
\hline No. & The factor & Rank (out of 189) & Distance to Frontier Score \\
\hline 1 & Starting Business & 168 & 63.15 \\
\hline 2 & Registering Property & 104 & 64.05 \\
\hline 3 & Dealing with Construction Permits & 28 & 82.49 \\
\hline 4 & Getting Electricity & 81 & 76.39 \\
\hline 5 & Getting Credit & 165 & 15.00 \\
\hline 6 & Trading Across Boarder & 168 & 38.58 \\
\hline 7 & Protecting Minority Investors & 154 & 41.67 \\
\hline 8 & Paying Taxes & 112 & 69.11 \\
\hline 9 & Enforcing Contracts & 50 & 65.43 \\
\hline 10 & Resolving Insolvency & 74 & 47.20 \\
\hline & The average & $\mathbf{1 3 2}$ & $\mathbf{5 6 . 3 1}$ \\
\hline
\end{tabular}

\footnotetext{
${ }^{1}$ http://www.csa.gov.et/

2 http://www.doingbusiness.org/reports
} 
Another research ${ }^{3}$ shows that $68 \%$ capital of SMEs come from savings of the promoters. The study shows that only $30 \%$ of the promoters were holding Diploma or higher qualification. $92 \%$ of the SMEs are sole proprietorship business and less than 10\% could speak English language. Only $23 \%$ promoters had better marketing skill, an essential skill for success of an enterprise. $55 \%$ promoters felt access to finance \& marketing as bottleneck \& problem for their success. $77 \%$ of the enterprises are managed by self or family.

Looking to the investment bottleneck, the best strategy for Ethiopia is family based, and small \& medium small enterprises (SME), which can be driver of economic growth and social development. SMEs can increase per capita income, improve gini index, better social conditions and improve overall business environment. For developing country, to promote SMEs is a winning strategy, which decentralize the wealth more equitably compared to the large industry. SMEs create local employment; direct \& indirect. SMEs can be feeder to the large industries. SMEs can be tool for exploiting local innovations and enhance consumer life conditions. It is necessary for the big industry to be proactive \& innovative to survive and grow. To be receptive and reactive for them may be dangerous, as their survival \& recovery cost is comparatively high. Whereas it is good if SMEs are proactive, but they can survive and grow by being receptive \& reactive also, as they have better flexibility to survive with lesser recovery cost. As SMEs require lesser investment, risk of losing money is less due to larger portfolio management at macro level. It is easy and speedier to set up a small unit. The proximity of SMEs with the end consumer and suppliers is closer. SMEs use simple skill, local raw materials and hence have direct impact on local socio-economic conditions. SMEs in smaller towns can help prevent migration of local people with larger impact on life of citizen, hence Ethiopia should give emphasize on SMEs.

\section{Research Methodology:}

The research will use secondary data in form of policy and statistics documents, contemporary relevant research and informal but reliable quotes. We will develop questionnaire for entrepreneurs, consumers, suppliers, financial institutes, government officers and political leaders to gauge the pulse. The data will be analyzed using appropriate statistical \& research tools. We may consider using semi structured questionnaire to open up new factors responsible for promoting SMEs. We will study tools \& techniques used by other successful developed countries to ascertain what befits in Ethiopian business environment to promote SMEs.

\section{Finding \& Beneficiary:}

The research aims to analyze data to find reasons of low entrepreneurship and low contribution of SMEs to suggest policy makers to address low ranking of doing business and supportive environment for SMEs. The research will pin point role of government, social institutes, financial institutes and entrepreneurs in context of prevailing Ethiopian business environment. Using tools \& techniques used by other successful developing country, Ethiopian government, entrepreneurs \& financial institutes can take cue to adopt some of them in short, medium \& long run.

\footnotetext{
${ }^{3}$ Entrepreneurship with Special Reference to the Status of Small Business Entrepreneurship: A Case Study Of Gondar, Ethiopia by Friday O Okpara \& Ato Davit Mengistie
} 